\title{
12
}

\section{From Donation to Handout: Resource Wealth and Transformations of Leadership in Huli Politics}

\author{
Michael Main
}

In the decade since ExxonMobil's vast Papua New Guinea Liquefied Natural Gas (PNG LNG) project began construction work in what is now Hela Province in the Papua New Guinea (PNG) highlands, the Huli owners of the gas resource (referred to in this chapter as 'landowners') stand as a prime example of a population cursed by the unequal distribution of extracted resource wealth. In the case of PNG LNG, these inequalities are global in scale and include the enrichment of offshore investors in addition to a corrupt political elite that retains power in PNG, no matter how starkly their fraudulent means to power are exposed (see Haley $\&$ Zubrinich, 2018). Frustration over the lack of promised development benefits from the project, including the non-payment of landowner royalties, has fuelled a history of conflict and unresolved grievance within the population-who are the customary landowners of the resource area-that has resulted in the most resource-rich province in PNG also experiencing the most extreme levels of violence.

In the wake of the development failure that is the PNG LNG project, traditional forms of leadership that ushered the project into existence are also seen to have failed, as Huli society experiences increasing levels of frustration and social disorder. Traditional methods of obtaining political 
power have given way to a more pragmatic leadership style that no longer relies on mythological and cosmological understandings of development and wealth. The failure of Huli elites to deliver on the development promises of the PNG LNG project has resulted in a transformation of leadership forms and the emergence of the honorific title 'paramount chief' in a system that has no tradition of chiefly leadership roles.

The PNG LNG project's reneging on its development promises at the local level is, at least in part, a reflection of its deficiencies in delivering on its much-lauded macro-economic benefits to the PNG state. Constructed at the cost of USD 19 billion, the PNG LNG project is the largest resource extraction project in the history of the Pacific region. At the time of writing, the project is producing 8.8 million tonnes per annum (MTPA), which is well above its nameplate production rate of 6.9 MTPA. ${ }^{1}$ In its first four years of operation, the project is estimated to have generated USD 18.8 billion for ExxonMobil alone, which owns a 33.2 per cent stake in the project (Barrett \& Gloystein, 2018). In November 2018, the PNG treasury halved its forecast for expected revenue from the project to USD 11 billion over 26 years to 2040. However, according to a recent World Bank report, the PNG LNG project:

is authorised to hold its foreign currency earnings in offshore accounts without first having to pass it through PNG's domestic spot market. Together with generous tax concessions, this means that without a large rebound in LNG [liquefied natural gas] prices, the project is unlikely to be a major source of foreign currency inflows for at least the first 10 years of production. (World Bank, 2019, p. 19)

The macro-scale inequalities of the PNG LNG project have fed into inequalities experienced at the local level. Huli landowners of the gas resource are enraged that the project has delivered very little of the infrastructure that they were promised. Before project construction began in 2010, landowners and the state signed Landowner Benefit Sharing Agreements that promised roads, power supply, schools and hospitals. These agreements were not signed by ExxonMobil. Therefore, it is to the state that Huli landowners look in their expectation of benefits and infrastructure projects. Huli attitudes towards ExxonMobil are best described as ambivalent. The ideal model of the state collecting

1 'Nameplate' is the industry term used to denote a nominal rate of expected production. 
resource revenues and using those to provide services is broadly embraced by landowners. However, in the face of state failure to deliver on its expectations, many landowners expect the company to take up the slack. Oil Search, via the Oil Search Foundation, ${ }^{2}$ has been operating in PNG long enough to have learned this lesson and has made large investments in the Hela provincial health system. ExxonMobil makes largely symbolic gestures; however, as a matter of corporate policy, it does not engage in state-like development programs. ExxonMobil is criticised for this, sometimes publicly, as detailed later in this chapter. However, it remains the case that the advent of the PNG LNG project has resulted in heightened expectations of the state, which have given rise to a profound reinterpretation of traditional Huli hierarchies and understandings of leadership because Huli recognise that access to resource benefits can only be gained via the hierarchical structures that connect Huli landowners to state power. Hierarchies are necessarily unequal, requiring certain individuals to be endowed with more social efficacy than is held by other individuals in the general population.

In this chapter, I argue that Huli desire an effective hierarchy that supports individuals who have access to state power and are capable of accumulating wealth via access to power. The ideal Huli leader has become a wealthy and powerful individual who can facilitate the development of Hela Province for the benefit of the people. This chapter examines ways in which traditional forms of Huli leadership have been eclipsed by expectations of resource wealth and development, culminating in the construction of the PNG LNG project. In recent years, these Huli leaders have proven to be adept at accumulating wealth for themselves, but have not applied their wealth and power towards improving the lives of the people of Hela.

\section{The Huli Paramount Chief}

In her analysis of leadership in the Southern Massim region, Martha Macintyre critiqued a myth, frequently expressed in anthropological writings on Melanesia, that traditional leadership was both ahistorical and based on some egalitarian ideal (1994). Writing of Massim communities,

2 The Oil Search Foundation is the development arm of Oil Search Limited (OSL). Founded in 1929 and incorporated in PNG, OSL is the largest oil and gas company in PNG; it operates all PNG's oil fields, in addition to having substantial interest in all its gas fields. 
Macintyre argued that there was great flexibility in the nature of power and that leadership could be both hereditary and newly forged. Exposing the myth of 'first among equals' as an 'oxymoron' (p. 259), Macintyre uncovered a logic of underlying inequality in Massim societies. This analysis finds parallels in patterns of leadership among Huli, especially in the current era of LNG extraction. In particular, the relatively recent adoption of the terms 'chief' and, more recently, 'paramount chief' among Huli to express admiration for various leaders must be understood in the context of shifting power relations and the exploitation of natural gas reserves since the 1990s. Huli have been surprisingly late to adopt these titles, which have been in widespread use across PNG for many decades and have done so in the absence of any equivalent Huli term or understanding. Macintyre wrote that use of the term 'paramount chief' in PNG can be traced to Malinowski, via his supervisor Charles Seligman, who accepted the term that was invented in 1896 by the LieutenantGovernor of British New Guinea, Sir William Macgregor. Whereas 'the Trobriands as the site of an endogenous hereditary hierarchy' was an invention of Malinowski (Macintyre, 1994, p. 248), the recent Huli adoption of chieftainship is a response to the exploitation of oil and gas reserves within Huli territory. In both cases, new forms of leadership have been adopted as 'an opportunistic response' (p. 251) to new opportunities afforded by access to external sources of wealth and power.

Similar 'inventions of tradition' have been documented for other sites of resource extraction in different parts of PNG. Like Huli, Lihirians 'had no customary institution of hereditary chieftainship'; however, unlike Huli, they decided to invent a 'Council of Chiefs' 'through which to regulate the process of development' that was expected from the Lihir gold mine (Filer, 1997, p. 177). Huli apply the title to individuals who might be able to facilitate the process of development from the PNG LNG project. Macintyre's radical proposal is that the invention of tradition is not a feature of modernity, but rather a fundamental component of tradition itself. In her analysis of the adoption of the title 'paramount chief' sometime in the 1920 s by a prominent man on the island of Murua, Macintyre (1994) argued that this transformation of Muruan social relationships should be read in terms of the capacity for a particular Maruan individual to 'adapt, transform and transcend' these relationships and cultural norms. Macintyre was revisiting the work of Fred Damon (1983), who argued that the title had been adopted 'even though there is no such position in the culture' (p. 45). For Macintyre, such a statement 
'is to reify, conceptually and temporally, an array of set characteristics that are not susceptible to change' (1994, p. 250). In other words, it was not a case of culture being abandoned, but rather culture as a historicised and transformative process that responds, often via the specifics of individual agency, to new opportunities and new realities. In the case of the Muruan leader, it was an opportunistic response to colonial understandings of land ownership so that he could obtain ownership of a resource that had previously been held communally. The new Huli 'chiefdom', and particularly the more recent 'paramount chiefdom', is explicitly related to the desire to access resource wealth.

The first Huli ethnography, undertaken by Robert Glasse during the 1950 s, states that 'Huli have no chiefs or hereditary offices vested with political authority' (1968, p. 21). Subsequent ethnographies of Huli (barring my own contribution) make no mention of chiefs; however, newspaper articles and social media posts since the PNG LNG project began construction make frequent reference to the Huli 'paramount chief' in describing certain individuals who hold great leadership status. Prior to the addition of the adjective 'paramount', the use of the term 'chief' in Huli has been traced directly to the actions of British Petroleum (BP) in 1989 when drilling an exploratory well at Angore in what is now Hela Province. In his Corporate History of Hides, the former Community Affairs Adviser for Oil Search wrote:

It is worthwhile explaining how the title 'chief' has come to be used among the Huli, since the practice is linked to the drilling of the Angore-1A well. Traditionally, Huli does not have a hierarchical society-there are no chiefs.

In 1989, when the Angore well was being drilled, BP employed a number of the local leaders, basically on sinecures, to advise BP which people should be taken on as labour - according to their clan ties. The senior person amongst these was Minule Arawi, as the senior landowner. A BP drilling supervisor at the time was Ernie Hardman. He gave Minule a hard hat with the word 'chief' stencilled on it. From that time the practice has grown among the Huli and now every clan leader in the general Hides/Karius area is styled a 'chief'. (Clapp, 2002, p. 44)

Although Clapp is correct in stating that, traditionally, there were no Huli chiefs, Huli society was, and remains, hierarchical. It is this hierarchy that was transformed in the adoption of chiefly titles. 
The earliest reference I have found to 'paramount chief' for Huli is in a February 2007 article in the Papua New Guinea Post-Courier: 'paramount chiefs from the Hiwa Komo clan in the Hides gas project area are in Port Moresby to see the Ombudsman Commission to push for a possible referral of the deal to the watchdog' (Papua New Guinea Post-Courier, 2007). The article refers to a proposed deal between PNG Power Limited and Hides Joint Venture Limited to supply gas-generated electricity to the Ramu Nickel mine site. Hiwa is a major clan group that has been involved in disputes over land related to the extraction of gas at Hides since 1990 (Clapp, 2002, p. 217). The phrase 'paramount chief' does not appear in any of the numerous 'social mapping reports' 3 that were produced by anthropologists as part of the suite of baseline studies undertaken prior to the beginning of the PNG LNG project. A 2005 letter from the Hiwa Tuguba Hides Association to the Minister for Petroleum and Energy, highlighting landowner issues at Hides that they wanted the minister to resolve, refers to Wandiago Gihamua as 'Chief of Hiwa tribe'. It is possible that the term 'paramount chief' was introduced to Huli via an act of journalistic flair. Whatever the case, there are important differences in the deployment of this term between its Huli use and its much earlier use on the island of Murua.

Although I encountered the term many times during my fieldwork in Hela, it was always in the context of a leader being described by someone else. I never heard anyone describe themselves in that way, although I did meet some people who had the title bestowed upon them. In Huli, 'paramount chief' is more often an expression of admiration for a particular individual and of the desire for such a hierarchical structure to exist. It is also performative-a particularly salient example of this was the moment in 2015 when the (former) PNG prime minister Peter O’Neill visited Tari, the capital of Hela Province, and was accorded the status of 'a paramount chief when he was presented the unique Huli wig and headdress that is only worn by Hela chiefs' (Elapa, 2015). O'Neill had arrived in Tari to announce the commitment of PGK 600 million 'for infrastructure developments' for the province-money that was supposedly coming from the PNG LNG project, but that would never materialise. There is certainly no such wig that is used to identify Hela chiefs, except that on this particular day there was- the point of the exercise was to reinforce

3 'Social mapping and landowner identification studies' are a requirement of the PNG Oil and Gas Act. These studies are to identify and describe landowning groups, including their social organisation and cultural methods of land ownership. 
a link to wealth and political power that could be harnessed for the benefit of the province. Huli paramount chiefs are usually the heads of major clan groups and, when things become really serious, several can gather together - the veritable full bench of paramount chiefs - to make their case to the national government in Port Moresby. The term is deployed loosely, in a way that reflects the nebulous nature of Huli leadership, which I describe below. To understand these transformations of Huli culture and social relationships, it is necessary to revisit early Huli ethnography that has itself become a historical artefact.

\section{Transformations of Huli Leadership}

In 1959, the American anthropologist Robert Glasse published the first two ethnographic works on Huli, in the form of two journal articles: 'The Huli descent system: A preliminary account' and 'Revenge and redress among the Huli: A preliminary account' (Glasse, 1959a, 1959b). In these papers, Glasse described two parallel hierarchies that exist in Huli society. In 'The Huli descent system', Glasse pointed out that it is only certain 'experts' who possess extensive genealogical knowledge; these people are called upon to facilitate in dispute resolution and to officiate in ritual ceremonies. These experts are holders of an inherited form of knowledge that is passed agnatically though particular family lines.

In 'Revenge and redress', Glasse described the existence of great disparities in wealth and social status between people, which are based on differences of individual ability and volition. Different people will own different numbers of pigs, have more or fewer wives and maintain residence rights over greater or lesser portions of land. Glasse even divided male Huli into three categories of person: those with low, average and high social status. Glasse avoided stating that these three categories find certain analogy with class distinctions observed in Western societies. However, the comparisons are obvious: one major difference being that Huli status distinctions were based on individual ability and desire, rather than the structural conditions of society. This was certainly the case during my fieldwork in 2016, when I found that status differences are, to an extent, understood in moral terms and resonate with the neoliberal economic ideal of individual responsibility. Therefore, there is an element in the persistence of Huli inequality that is seen to mirror immoral behaviour. 
There is an ethos of individualism in Huli that cannot be overstated. Unlike other highlands groups, Huli cultural praxis is oriented towards the service of the individual rather than the collective. Huli prioritise and respect individual ambition and choice. Conflict always occurs between individuals rather than clans and group alliances form around individuals, based on a combination of kinship, clan affiliation, residence and friendship. Different people display different levels of individual ambition and ability and the stratification of Huli society into different levels of social efficacy, and material wealth has encountered the era of resource extraction and the opportunities for great wealth and prosperity with no small degree of familiarity.

Thus, there are two parallel leadership systems that exist for Huli: one that is based on inheritance and the other on effort. Both systems exclude women - the first on the basis that genealogical knowledge is agnatic and the second on the basis that land ownership is agnatic. Holly Wardlow (2006, p. 69) described the exclusion of Huli women from taking positions of power in terms of a 'collective agency' that is less available to women. Genealogical knowledge and land ownership are intimately related. The type of leadership bestowed upon certain people whom Glasse described as 'experts' is inherited and based on the knowledge that is passed from father to son within particular genealogical units. This form of leadership is also stratified and includes clan leaders in addition to regional leaders. Every clan has a family line that holds detailed genealogical and historical information about the clan.

The men who hold this information are known in Huli as agali haguene, or 'head man'. ${ }^{4}$ Agali haguene are relied upon for their trusted knowledge in the complex system of land ownership and to assist in the resolution of disputes over claims to land. The average man, as accurately described by Glasse, has extensive knowledge of his own genealogical history, but not the vast trove of historical knowledge possessed by the agali haguene. This system should not be thought of as rigid, as claims to land are strongly influenced by competition between individuals and land disputes occur between those who claim to have superior knowledge. To possess knowledge and to use that knowledge in disputes over land are two different things. Further, prior to the influence of resource extraction projects, Huli historical knowledge, called dindi malu, or 'land history',

4 Agali = 'man' and haguene $=$ 'head'. Note that this noun is not pluralised. Agali means 'men' in the plural context, with the plural form indicated by the context and verb suffix. 
was considered to be a shared resource, albeit one that only came to the surface during disputes over land. Land disputes, where dindi malu is spoken and contested, are public performances held in open space, referred to in Huli as hama. Ultimately, Huli believe that a singular truth binds everyone together; land disputes are contested in the pursuit of that truth.

The Huli word gimbu means 'bind' or 'join together'; the establishment of the Hela Gimbu Association in the 1960s constituted an attempt to bring together the definitive set of knowledge required to complete the Hela historical narrative. Huli despaired at the loss of knowledge that was successively occurring for each new generation-they still do this. Loss of Huli mana, which 'encapsulates a socio-historical accounting of knowledge' (Goldman, 1983, p. 67), was part of the perceived 'entropic' decline that included the fertility of the land and people. However, it is simultaneously true that those with superior knowledge and rhetorical skill are likely to win the argument in a land dispute and that knowledge is constantly being created in the prosecution of land disputes. Rhetorical skill in the construction of an argument in itself provides evidence for objective truth. Therefore, individuals possess the power to create truth, and Huli social structure is in a constant state of 'becoming' (Goldman, 1993 , p. 23). Thus, individual desire for accumulation of wealth and social status goes hand in hand with the desire to accumulate knowledge and create new truth.

At the regional scale, holders of inherited knowledge are known as dindi pongoneyi, or 'land root man'. ${ }^{5}$ These days, dindi pongoneyi are sometimes referred to in English by Huli as 'high priests'. 'High priest' is not an unreasonable analogy, as the dindi pongoneyi possessed very restricted knowledge about ritual practices and had access to the most sacred sites in Huli territory. There are only a handful of family lines that hold dindi pongoneyi status; these are widely known among Huli today. In Glasse's time, the role of the dindi pongoneyi was, quite literally, to prevent the world from ending and ensure the maintenance of the health and fertility of both land and people. Currently, they are called upon to facilitate in claims over clan rights to benefits from the PNG LNG project.

5 Pongone $=$ 'root' and the suffix ' $-y i$ ' = 'man'. Note that this noun is not pluralised. The plural form is indicated by the context and verb suffix. 
I came to know one dindi pongoneyi named Allan Ango; the extent of his influence was extraordinary. Ango was born in Koroba and gave much of his land to the Koroba Catholic mission after it established itself during the 1950s. Allan Ango was among the last generation of Huli to have lived his school-age years prior to the establishment of an Australian administration presence and the arrival of mission schools. Ango was fluent in the languages of neighbouring groups but spoke no English. However, Ango, like many other Huli, instantly recognised the importance and value of the white man's education and the access it granted to the wider world of material wealth and wellbeing that was rapidly being introduced into the PNG highlands. Huli ritual leaders such as Ango wasted no time in their reinterpretation of Huli mythology and cosmology, to the effect that the coming of Western modernity had been clearly prophesised by the ancestors. In this way, Western modernity, including its education and health systems, were pre-encompassed by Huli and already formed part of a prophesised Huli destiny. In embracing Western education, Huli were embracing something that (from their perspective) already belonged to them, and that was already part of what it meant to be Huli.

Ango seemed to be constantly on the move, travelling slowly with his walking stick but never stopping and forever in the process of checking in with his extended network. This network stretches all the way from Koroba to the Papuan Plateau. After spending time with Ango in Koroba, I travelled with him by car all the way to Komo, a journey of several hours. Ango had to sit in the back of the car hidden from view; if people knew that he was there, we would have been constantly stopped by anyone wanting a piece of his knowledge- this was an issue for us along the entire journey. At Komo, I went to church with Ango, who was surrounded by people asking for all kinds of advice and knowledge. A local schoolteacher even said to me, 'I want to know about the names for birds. In school, we are only taught one word, ega, but ega just means "bird". Huli have words for all the different types of birds.' During Ango's stay with us in Komo, we were visited by the president of Bosavi district, Efela Babe. Bosavi district straddles the southern part of Hela Province, from the southern side of Mt Sisa to the Papuan Plateau. Ango met and conversed with Babe in fluent Etolo. Babe had earlier consulted with Ango over Etolo genealogical connections with Hela, the apical ancestor who, in the Huli narrative, united all the clans of Hela Province and many beyond. Babe had sought this information during his campaign for election as Bosavi president. Babe had witnessed the success of the revered Southern 
Highlands Governor and later Hela Governor, Andisen Agiru, after he had turned to Ango for knowledge that he used for his political campaign. In turning to Ango for information, both Agiru and Babe were emulating the 'expert' leadership style described by Glasse.

Agiru came to power in 1997, more than 10 years before the PNG LNG agreements were signed. He had been instrumental in negotiations over the PNG LNG project and was a very popular leader. Agiru, I was told, was descended from a dindi pongoneyi with the ancestral name of Pawa. I am unable to verify Agiru's genealogical origins; however, the critical point is that Agiru constructed his own identity in these terms and was revered as such by his supporters. One person explained to me his view of Agiru and his role in the PNG LNG project as follows:

He brought negotiations, agreement with that he came. It's like Moses in the Bible who led Israel from Egypt to the Canaan land on the mountain he died. So, after negotiations and then the gas flow the people to get payment he died.

The dindi pongoneyi families had been quick to adopt Christianity, through which they readily reinterpreted their own traditions. The adoption of Christianity by Huli reflected a self-positioning of Huli as always being at the centre of the universe, both economically and cosmologically. Therefore, Christianity was not interpreted as something foreign, but rather as something that had been prefigured in Huli tradition and to which Huli were ancestrally entitled. Agiru embraced an evangelical form of Christianity; he was convinced that Huli were descended from the Israelites and even made trips to Israel, where he was said to have purchased land (Cox, 2015). The analogy of Moses leading the Israelites is a typical example of Huli use of Christianity to place Huli at the centre of matters of importance. This also reflects a Huli desire to support the elevation of their leaders to positions of great authority. In the transcript of Agiru's speech at Kokopo provided below, Agiru describes the PNG LNG gas as 'spiritual gas to fulfil the great commission blong [of] world evangelism'.

Agiru was from a distinguished Huli family line and had received a good education that resulted in him attending university in Port Moresby. When Agiru decided that he wanted to run for political office, he realised that, to win Huli votes, he needed to be able to speak to the people in terms of their own shared Huli identity. To relate to the majority of Huli living in bush-material houses, raising pigs and tending sweet 
potato gardens, Agiru referred to their shared Huli dindi malu. That is, by invoking the names of clans and ancestors and associated landscape features, their praise terms and patronyms, he was able to tap in to deeply held sentimental feelings that Huli possess concerning their homeland. By displaying such a wealth of knowledge spread across the vast expanse of Huli territory, he could demonstrate a superior intellect that was governed by benevolent intentions.

Agiru returned to his Huli homeland and set about learning all he could about Huli dindi malu. As a descendant of a dindi pongoneyi, Agiru was able to call upon the services of Allan Ango and other Huli elders. Agiru's political genius was explained to me by Michael Ango, the son of Allan Ango. Michael had witnessed Agiru's transition into a politician when Agiru came to live with Allan Ango to learn from him. Michael explained that:

He praised the mountains, he praised the rivers, he praised the clans and then 'you are the son of this man, you are the son of this man, you are my relative, you are my people, you are my daughter, your village is here, your house is here, your river is this one.' And 'how did this man know my mountain? How did this man know my clan? How did this man know my family?' Okay then we go to put this man first. So the people realised that 'Oh Agiru called my name, I have never known Agiru before. He called my father, he called my name, he called my river, he called my village, he called my garden, he called my mountain'. Everybody started thinking of Agiru. 'We want Agiru, we want Agiru'. From kids to old men. Because other candidates they never call our village, our place, our home, our family tribes, family names, our clan. So this man called our clan names, our mountain, our village, our place, our fathers.

It is difficult to convey via translation just how deeply sentimental the Huli language is. Sentimental expression is conveyed via 'the mechanics of synonym substitutions and metamorphoses of sound shape' (Goldman, 1998, p. 66). The calling of genealogical names and associated landforms includes the deployment of a vast trove of praise names; metaphoric replacement terms charge the language with extraordinary pathos. To 'be a competent communication' in Huli 'demands an understanding of the structural and discoursal salience of renamings' (Goldman, 1998, p. 66). 
Anderson Agiru had an extraordinary gift for Huli political rhetoric and, in the social and political context of his day, political power in Huli was accessible via the deployment of such rhetorical gifts. Agiru was also a confirmed bachelor-this aspect of his life had deep connections to traditional Huli beliefs about moral purity. Huli traditionally maintained a belief in the polluting power of women and, particularly, the extraordinary danger posed by menstrual blood. Huli men and women lived separate lives and men maintained their own gardens and avoided eating food that was grown and harvested by women. The Huli bachelor cult, known as haroli, involved young men living for two to three years together in the bush, learning complex rituals and spells, particularly relating to how to avoid becoming contaminated by female contact. When organising hunting trips into the high forest, Huli men would prepare by avoiding sex for several months to purify themselves. The multitude of moral codes of behaviour are known in Huli as ilili (forbidden acts); many of these relate to purity and the avoidance of female contact. Agiru maintained a reputation for moral purity and stood as an example of a Huli ore, or 'pure Huli', partly via his status as a bachelor.

\section{Death of a Great Language}

During the Umbrella Benefits Sharing Agreement meeting for the PNG LNG project held at Kokopo in April 2009, Andisen Agiru gave a speech to the attendees in Huli. Agiru's speech was reportedly much lauded and laden with Huli mythology and traditional knowledge that he skilfully linked to the project and the expected future for the Huli people. Agiru's speech in Huli was not recorded; however, a recording does exist of the speech that he gave in English on day three of the forum, which begins: 'the greatest river unbreached is the river of time'. This does not correspond to any known Huli speech form or saying, and it is likely that nobody exactly knew what he was talking about. However, it is both evocative and typical of Agiru's style of harnessing devotion through the deployment of pathos and rhetorical skill. Agiru then went on to credit himself for the return to power of the then prime minister Michael Somare. According to Agiru, in 2001, he made a prophecy that Somare would return to power and that the speaking of his prophetic words put into action events that resulted in the return of Somare to the prime ministership: 
Let us pause for a while [no pause]. The date 2nd August 2001, at a village called [indecipherable] the speaker for the National Parliament then, Dr Narakobi, Mr Alfred Kiabe, member for Komo-Margarima, Bart Philemon, then was in government now the member for Lae, the then-member for Wapenamanda, Masket Langalio, myself and my brother Somare. We stood there and on that day doing ground breaking ceremony to connect the peoples of [indecipherable]. We did that ground breaking ceremony on that day and I spoke and prophesised that Grand Chief will form government again in 2002. That was on the 2nd August 2002 [Agiru means to say 2001]. Two weeks later, he was sacked as foreign affairs minister, Minister for Foreign Affairs. If I had not made that statement, he would not have been sacked. I made that statement and, as a result, the ball started rolling for the emergence of the government we have today, our government. It is thanks to the government of Sir Michael that there is going to be a PNG LNG project.

Agiru simultaneously credits himself for the existence of both the Somare government and the PNG LNG project.

This belief in the material agency of the spoken word is very much part of a Huli ontology of speech. For Huli, 'saying words is a production of material effects' (Goldman, 1983, p. 36). With the power of speech at his disposal, Agiru then went on to make various promises, many of which had little or nothing to do with any of the signed agreements:

A child at school in the Hela world today will have the knowhow. I will lend him my torch to search. He may then come and make an offer to buy out ExxonMobil! [applause]. My today's limitations will be something of the past then ... I need to build and seal a highway from the Gulf at Kikori, through Kutubu to Tari [cheers]. I need to build and seal a highway from Kiam to Kisina Pori at Ialibu. I need to upgrade and seal Mendi to Lake Kopiago highway ... I need to upgrade and seal the road from Margarima to Kandep into Wabag. Seal the road from Hides to Fugua. [Several roads later] Telefomin to East and West Sepik. Build a new road from Juha down to the Fly. And of course, why not? I'll build a freeway from Tari International Airport to the Hides gas plant into Komo ... The airport at Kikori has been talked about, it's part of decision 24 of 98 . I need to build a wharf, international wharf through private public partnership at Kikori [applause]. Why build a road if there is no wharf? Cities around the world are built around airport. Why have an international 
airport up in Tari? I need to build Hela City [applause]. And that is one of the most critical projects because royalty, na equity, na em blo' papa graun tasol, and the provincial government, local level. Minister blo' trade and industry, or commerce and industry, I want Tari declared a tax-free zone [applause]. I want to expand Mendi township and the township of Ialibu. [Several townships and several hospitals later] Education is dear to my heart. For my people there must be a university in the Southern Highlands, especially the Hela area. That university must be built in the Komo-Margarima electorate. Hela Technical College, those who fail to go to university must go there to upgrade their learning. That technical college must be built in the Tari-Pori electorate. The Hela International School of Culture, Language and the Arts. The culture and arts of Melanesia is fast diminishing. We need to go back and start teaching art and craft and culture back at school so that we do not lose our identity. And that institution must be built in the Koroba-Lake Kopiago electorate ... Future generations fund. Applying the Alaskan and Norwegian models we propose to invest part of our benefits accruing from the oil and gas business, the Southern Highlands Provincial Government and Hela Provincial Government will invest fund blo' future. Whatever money is given to our province we will give priority to investment in women and youth development. We will because it is our spiritual gas to fulfil the great commission blong world evangelism. Provincial government blong tupla province by setting money aside lo displa fund. We will insist that landowners do the same.

In his chapter for this volume, John Cox writes of the differentiation between what are seen as the 'legitimate aspirations' of the 'rural grassroots' versus those of the 'urban middle class'. When Agiru declared that he wanted to build a Hela City, he was legitimising the aspirations of those living a more traditional lifestyle — the subsistence farmers living in bush-material houses who were looking for a leader to deliver them into modernity. The populist largesse of Agiru's rhetoric makes sense in the context of a Huli understanding that material reality is brought into being via the act of speech. Agiru's words had brought Somare back to power, and his words would likewise bring to fruition his vision for the future of Hela. Agiru was reaching deep into traditional Huli understandings of the power of the act of speech. He had been emboldened by his success, thus far, in returning Somare to power and bringing the PNG LNG project into material reality. At Kokopo in April 2009, Agiru gave it everything he had. 
The day that Agiru died, I was in Tari; all around me, the people of Hela had gone into a deep mourning. The most immediate and obvious impact of his death was a cessation of the fighting that had ravaged Tari for months. The conflict had arisen from a complex dispute related to compensation payments for Tari airport land after it was expanded to accept heavier aircraft that were needed during the construction of the PNG LNG project. Out of respect for Agiru, all fighting was suspended and even the two rival candidates for his replacement, Francis Potobe and Philip Undialu, restrained themselves from politicising the situation. However, by that time, some had begun to complain openly about Agiru's failure to deliver on his promises. Many people even spoke to me about Agiru's ill health and death being the direct result of him giving away their gas for nothing. This particular observation relates to a Huli prophecy associated with the mountain that hosts the gas resource. According to the prophecy, underneath Hides ridge (known in Huli as Gigira) is an eternal fire- a giant, smouldering piece of wood. One day a man with red legs will come and ask for the fire. The landowners of Gigira may share some of the fire with him, but they are not to give all the fire away, lest the world come to an end. The failure of the PNG LNG project to deliver on its promises is widely viewed in terms of the fulfilment of this prophecy.

In many ways, Agiru was the last of a kind; however, PNG LNG had transformed him into something unique. The absence of benefits from PNG LNG had exposed Agiru's beautiful rhetoric as something hollow and powerless; it seems unlikely that a leader such as Agiru will ever emerge again.

\section{It's About the Money, Stupid}

Agiru left behind a political environment that was vastly different from the one that had existed when he first came to power. The rivalry between his would-be successors Potobe and Undialu centred around the issue of development and who was best placed to address frustrations over the failure of the PNG LNG project to live up to its promises, not to mention the failure of Agiru's vision. When these two politicians spoke to the people, they did so in the language of development rather than culture or tradition. On 5 October 2016, a public ceremony marked the handover of Tari hospital administration to the Oil Search Foundation and the appointment of the Oil Search Managing Director, Peter Botten, 
as chair of the Tari Hospital Board. At the time, the governorship had been assumed by Francis Potobe; however, he was later successfully challenged by Undialu.

During the ceremony, Francis Potobe gave a speech in English that perfectly captured these feelings of frustration and spoke directly to the needs and desires of the Huli population. Potobe's speech was delivered to a large Huli crowd in Tari; however, it contained almost no reference to Huli culture or tradition, apart from a negative allusion to the Huli practice of fence building:

Now as the new Governor of Hela Province [cheers] ... It is not easy to be a public servant in this part of the country. Plenty of public servants want to enjoy a better life. But for Hela public servants whether policemen, nurses, doctors, teachers, life em hard ... here. Me together with minister Marape and Peter O'Neil together with man blong here and meri blong here we grew up in the area where Hela leaders are fence builders. Hela leaders are fence builders ... Hela go bush, haus sik [hospital] go bush, community school go bush, airport bagarap [broken]. No got telephone, no power line, no nothing because our leaders are fence builders. [cheers] ... road project ... rate of return is nothing! The Highlands Highway go down, the Tari hospital go down, Tari airport go down, everything go down in the land where we produce oil and gas our leaders are the fence builders. Minister Marape, Member Undialu ... must never be fence builders. We are not here to build fence. We are here to make sure haus sik em alright. When we are producing power in Hides. The power producers are leaving it for the government when power bypass us for many years because our leaders are fence builders ... Last 20 years, 40 years we are fence builders ... You must not be a fence builder, you must be a service provider. Haus sik must change, development must come ... I say thank you to Mr Peter Botten and the Oil Search team ... it's about time Oil Search put the foot down. I am yet to see ExxonMobil following in the footsteps of Oil Search ... Mr Botten when the doctors were pulling out you came on board and prime minister Peter O'Neil and ... we were forgotten by the health department for a long time. We were forgotten by education department for a long time. The mothers were delivering babies using the candle light or bamboo light. We were producing LNG and we don't produce leaders ... when I quit politics I will look back and say when I was a member of parliament I did these things. When you have leaders who are 
fence builders, when you have government who doesn't want to know what is happening in Koroba, Komo, Tari, Margarima, Benaria. School bagarap, haus sik bagarap, airport bagarap ... you are going to produce a society that is growing up without education, know nothing and what you expect lawlessness. Lawlessness ... Police ... police now 100 men for Hela. Koroba will have 40 policemen, Komo will have 40 policemen, Nogoli will have 20 policemen, Margarima will have 20 policemen. Tari will have two to three hundred policemen. Then we know we are almost there ... their children need to go to school, their family need to do shopping, they need a reliable airport, they need the reliable power and a company must work. We are launching big things. You look at the Komo airport, a big white elephant sitting in the countryside doing nothing ... Hela must be peaceful ... we happen to be the last people in this country all the time. Why? because the Highlands Highway stop here, everything stop here. So if that is the name of the game we play the game ... lock him up in the police station but there is nowhere else to keep them so they let them out and the next day they committing the crime again. That is the story blong Hela Province ...

Potobe's repeated references to fence building constituted a direct appeal for Huli to abandon their traditional approach to politics. A defining feature of Huli culture is the construction of mud walls around clan boundaries. Known as gana in Huli, these have the dual purpose of marking territory and providing defensive protection in times of war. On land that is unsuitable for the digging of trenches and the construction of mud walls, Huli construct wooden fences. Therefore, Potobe was calling for structural change in the ways that Huli have traditionally related to each other, to assist in producing the desired level of development. Melissa Demian (this volume) calls our attention to the figure of the anthropologist, who is relocated from a classic setting on the periphery to one that is rapidly being transformed into a metropole. In the context described above, I was witnessing the express desire of Huli to do exactly this-the struggle to transform Hela into a city was the struggle to relocate Hela from the periphery to an important, industrialised urban centre (for comparable aspirations in Lihir, see also Bainton, 2008, p. 293, this volume).

In the months that followed Agiru's death, Michael Ango announced that he intended to run for the Hela governorship during the upcoming elections. Michael had witnessed the way Agiru had prepared himself for 
politics and reckoned that, as the son of the dindi pongoneyi to whom Agiru had turned for knowledge, he was ideally placed to follow in his footsteps. Like Agiru, the younger Ango had received a Western education and obtained a tertiary degree in Port Moresby. Michael's degree was in civil drafting; the qualification took him to employment in Rabaul, where he also married. While Michael's education could not have been more different from that of his father, the elder Ango had encouraged his son's education as a desired form of Huli development and change. During a long hike with Michael, from Komo down to Bopole (the Etolo village of Efale Babe), Michael collected a type of moss from one of the river crossings that Huli use for bathing. Michael showed me this moss and told me that his father had said to him, 'now you use this moss in the river to clean yourself every day so that you are ready for school'. An embodied Huli tradition was being deployed in the preparation of a new and desired Huli future.

In 2009, Michael Ango returned to his Huli homeland from Rabaul, at the beginning of the construction phase of the PNG LNG project. Like many other diaspora Huli, Michael wanted to stake his claim to promised royalty payments from the project and to take advantage of the promised employment and business opportunities that were expected to flourish. Although Michael's knowledge of Huli genealogical clan history was a disrupted and truncated version of his father's expertise, it was nonetheless extensive. The younger Ango believed that he was well placed to assist in the highly complex 'clan vetting' and 'landowner identification' process that had begun prior to 2009 to identify the beneficiaries of the PNG LNG project, and still continues to this day (see Filer, 2019). Michael was recruited by a well-respected Duguba ${ }^{6}$ leader named Stanis Talu to assist with clan identification issues in the Nogoli area that were associated with Petroleum Development License Area 1. Michael was engaged in this (unpaid) work at the time of Agiru's death.

However, Michael was poor; he knew that he could not compete with the well-funded politicians of his day. With some funding, Michael had a vision for his political success and a vision for himself as the second coming of Andisen Agiru:

6 Duguba is the Huli name for the southern clans that exist on either side of the Karius Range and Mt Sisa. Some Duguba are Huli in language and practice, whereas others exist beyond the limits of Huli cultural identity, such as the Etolo clans. Duguba is both a cardinal term and a genealogical identifier. 
But just because I am poor in the vehicle and poor in campaign ... if someone support me for the campaign and maybe 500,000 for the truck and the campaign rally. This is in my brain so I will just campaign from Kopiago come to here, go from Tuandaga, go to Margarima, go to here, come ... No Agiru is not dead, Agiru is alive, there is someone like Agiru here already. Mike I'm telling the truth that if someone wants to back me even for the member or even for governor. Mike, Berabuli clan is everywhere in the three electorates of Hela Province. Koroba, Kopiago side, Tari side, TariPori side, Komo-Margarima side.

Ango's Berabuli clan is extensive and has a complex history that links its members to many locations in Hela. However, Michael's Beraboli relatives and friends openly mocked him for his political ambition. They accused him of having a mindset that belonged in the 1980s. In those days, they said, people used to gather up what money they could and donate to the political campaigns of their clan leaders. Now, in the era of PNG LNG, the people instead hold out their hands expecting to be paid for their votes.

Michael's friends were right and, in the months that followed, the only candidates who made any kind of impact were part of an elite group of Huli with access to power and money. The only candidate who ran on a platform that highlighted his expertise and skill was the CEO of the Tari hospital, Dr Hewali Hamiya. However, even Dr Hamiya was unable to compete with the political connections of the two main rival candidates, Philip Undialu and Francis Potobe. Huli voters wanted to be represented by a person with impressive leadership qualities, who had access to money and power. As such, the ideal Huli leader has become a benevolent strongman who is able to accumulate great wealth and influence that he will then use to develop Hela Province and improve the lives of the Huli people. Huli had no vested interest in a person like Michael Ango-who was poor, just like everyone else. Huli respect the ability of individuals to accumulate wealth, and they recognise that wealth accumulation is necessary to finance the development of the province. Huli desire the existence of wealthy and powerful leaders; therefore, they also desire the inequality that is necessarily part of the hierarchy that supports such leaders. 


\section{Transformations of Morality}

The leadership styles of contemporary Huli politicians draw on the interplay between two traditional styles of leadership, originally described by Glasse. Today, as in Glasse's time, Huli have great scope to determine for themselves what type of lives they want to lead, the ways in which they choose to express a Huli identity, the extent they wish to engage with the rich and complex palette of Huli culture and tradition and the degree of wealth and prestige that they are motivated to accumulate for themselves. The type of leadership embodied by the current Hela Governor is that of the man of great wealth and prestige described by Glasse in 'Revenge and redress'. When Anderson Agiru first came to power, he was more a reflection of the 'expert' Glasse described in 'The Huli descent system'. Prior to the PNG LNG project, Huli put their faith in the power of traditional knowledge to improve their lives, even if this knowledge had been reconfigured in response to Christianity and new material opportunities. In the era of PNG LNG, Huli have instead put their faith in the material wealth and political power that their leaders are able to accumulate and deploy on behalf of their own people. In both cases, Huli desire a form of leadership that depends on the unequal distribution of resources. In the first case, the most valuable resource is knowledge; in the second case, the most valuable resource is material wealth and power.

With the advent of PNG LNG, Agiru became an amalgamation of both types, who made much of Huli prophecy and mythology, which were perceived to underpin the project, while also accumulating great wealth for himself. However, by the time of Agiru's death, these had failed to deliver any of the expected benefits from the project; consequently, the power and salience of Agiru's knowledge had also failed. I have been unable to find any evidence of Agiru carrying the title 'paramount chief'he both preceded and eclipsed the introduction of that term. However, contemporary leaders are often described in this way. Contemporary leadership continues to carry a strong moral component; however, the moral component has also changed and is now largely based on contemporary rather than traditional beliefs.

In contemporary Huli politics, the married status of politicians is largely irrelevant. The moral component is reflected in the way people dress, by maintaining a healthy lifestyle and, particularly, honesty and integrity in the stewardship of resource wealth. Politicians display campaign photos 
of themselves in clean-cut suits and with smiling white teeth. My host while I was living in Komo, Charles Haluya, was a local-level politician who avoided chewing betel nut and did not smoke or drink. Charles has political ambition, and his concern for his appearance is part and parcel of the moral purity that he must maintain for political success. His approach has borne fruit and, since 2016, Charles became president of the KomoMargarima electorate, before being elected Deputy Governor of Hela Province. Charles' constituents do not expect the same of themselves; however, they do expect this of their leaders, whom they desire to be an ideal version of Huli potential. Charles had also built a guesthouse with funds made available during the construction phase of the PNG LNG project. The only guests that Charles ever hosted were myself and (before me) a police mobile squad contingent that were sent to protect the assets of the PNG LNG project. The accommodation of these police was paid for by ExxonMobil; however, Exxon paid the money to the police department in Port Moresby and Charles, inevitably, went unpaid. Charles was forced to eject the police from his guesthouse; they then found accommodation elsewhere. However, Charles maintained the large guesthouse, replete with mess hall and laundry, as a way of displaying himself as a hard-working individual who was able to solicit the support of friends and clansmen in the realisation of his goals. As an ordinary person living in a bush-material house, Charles would have no chance of political success. However, as a person who could demonstrate both the ability to accumulate wealth and influence and to manage that wealth in a sensible way, which includes the management of his personal life, Charles was giving himself the best chance of gaining the support of his community.

\section{Conclusion: Inequality and Urban Utopia}

Huli do not desire to be represented by an equal — rather, by a first among the people, who is able to achieve the development aspirations of the province. Further, Huli have never been egalitarian-the Huli example reinforces the point that 'claims for indigenous egalitarianism' in PNG (Macintyre, 1994) are contradicted by a logic of inequality upon which various forms of leadership depend. For the Huli case, I would go so far as to suggest that a tradition of individualism and respect for selfadvancement has parallels with the much-derided neoliberal economic ideal of the capitalist West. After all, Agiru did envision a day when a Huli 
would come to buy out ExxonMobil. With the exploitation of oil and gas resources in Huli territory, development aspirations have become supercharged; consequently, the desire for great leaders to exist-leaders who are unequal and better able than others to achieve results- has transformed traditional forms of Huli leadership into something that had hitherto been unheard of in Huli parlance: the Huli paramount chief.

This process has occurred partly due to the failure of traditional forms of knowledge to engage with the world of development adequately, resource extraction and global economics. However, this process also continues a tradition of Huli creativity in engaging with and adapting to a changing world. To paraphrase Macintyre (1994), writing about the transformation of Muruan culture, this transformation of Huli culture must be read not as 'estrangement from' Huli culture 'as a set of norms, institutions and social relationships', but of Huli 'capacity to adapt, transform and transcend it'. What remains is the desire for a better life and the inexhaustible search for ways in which to achieve what Huli not unreasonably believe to be their entitlement from the exploitation of their gas resource: a Hela city for all.

\section{References}

Bainton, N. (2008). The genesis and the escalation of desire and antipathy in the Lihir Islands, Papua New Guinea. The Journal of Pacific History, 43(3), 289-312.

Barrett, J. \& Gloystein, H. (2018, 7 March). Shakes and superstition: Exxon faces backlash in Papua New Guinea. Reuters. Retrieved from www.reuters.com/ article/us-papua-quake-exxon-insight/shakes-and-superstition-exxon-facesbacklash-in-papua-new-guinea-idUSKCN1GJ12S

Clapp, G. (2002). Corporate history of hides. Sydney, NSW: Oil Search Limited.

Cox, J. (2015). Israeli technicians and the post-colonial racial triangle in Papua New Guinea. Oceania, 85(3), 342-358.

Damon, F. H. (1983). On the transformation of Muyuw into Woodlark Island: Two minutes in December, 1974. The Journal of Pacific History, 18(1), 35-56.

Elapa, J. (2015, 20 October). Spokesman hails O'Neill's K600m pledge. Papua New Guinea Post-Courier. 
Filer, C. (1997). Compensation, rent and power in Papua New Guinea. In S. Toft (Ed.), Compensation for resource development in Papua New Guinea (pp. 156189). Canberra, ACT: The Australian National University.

Filer, C. (2019). Methods in the madness: The 'landowner problem' in the PNG $L N G$ project (Development Policy Centre Discussion Paper 76). Canberra, ACT: Crawford School of Public Policy, The Australian National University.

Glasse, R. (1959a). The Huli descent system: A preliminary account. Oceania, 29, 171-184.

Glasse, R. (1959b). Revenge and redress among the Huli: A preliminary account. Mankind, 5, 273-289.

Glasse, R. (1968). Huli of Papua: A cognatic descent system. Paris, France: Mouton $\&$ Co.

Goldman, L. (1983). Talk never dies: The language of Huli disputes. London, England: Tavistock.

Goldman, L. (1993). The culture of coincidence: Accident and absolute liability in Huli. Oxford, England: Clarendon Press.

Goldman, L. (1998). Child's play: Myth, mimesis and make-believe. Oxford, England: Berg.

Haley, N. \& Zubrinich, K. (2018). 2017 Papua New Guinea general elections: Election observation report. Canberra, ACT: Department of Pacific Affairs, The Australian National University.

Macintyre, M. (1994). Too many chiefs?: Leadership in the Massim in the colonial era. History and Anthropology, 7(1-4), 241-262.

Papua New Guinea Post-Courier. (2007, 27 February). PNG Power deal smells fishy. Papua New Guinea Post-Courier.

Wardlow, H. (2006). Wayward women: Sexuality and agency in a New Guinea society. Berkeley, CA: University of California Press.

World Bank. (2019). Papua New Guinea economic update, January 2019: Slower growth, better prospects. Washington, DC: World Bank. 
This text is taken from Unequal Lives: Gender, Race and Class in the Western Pacific, edited by Nicholas A. Bainton, Debra McDougall, Kalissa Alexeyeff and John Cox, published 2021 by ANU Press, The Australian National University, Canberra, Australia.

doi.org/10.22459/UE.2020.12 